\section{Cureus}

Received 06/22/2018

Review began 06/25/2018

Review ended 06/28/2018

Published 07/05/2018

\section{C) Copyright 2018}

Akhtar et al. This is an open access article distributed under the terms of the Creative Commons Attribution License CC-BY 3.0., which permits unrestricted use, distribution, and reproduction in any medium, provided the original author and source are credited.

\title{
Spilled Gallstones Silent for a Decade: A Case Report and Review of Literature
}

\author{
Aisha Akhtar ${ }^{1}$, Marvi M. Bukhari ${ }^{2}$, Usman Tariq ${ }^{3}$, Abu Baker Sheikh ${ }^{4}$, Fasih Sami Siddiqui ${ }^{2}$ \\ , Muhammad Saad Sohail ${ }^{5}$, Amina Khan ${ }^{6}$ \\ 1. Surgery, Texas Tech University Health Sciences Center, Lubbock, USA 2. Internal Medicine, Shifa \\ College Of Medicine, Islamabad, PAK 3. Research Assistant, Yale University School of Medicine, New \\ Haven, USA 4. Internal Medicine, University of New Mexico, Albuquerque, USA 5. Internal Medicine, \\ Shifa International Hospital, Islamabad, PAK 6. Internal Medicine, Shifa Tameer E Millat University/shifa \\ International Hospital, Islamabad, PAK
}

$\square$ Corresponding author: Usman Tariq, usman.tariq8791@gmail.com

Disclosures can be found in Additional Information at the end of the article

\section{Abstract}

Laparoscopic cholecystectomy is associated with complications such as gallbladder perforation and spillage of gallstones. While these shortcomings are common, the occurrence of the resultant nuisances, such as intra-abdominal abscesses, is infrequent. We present the case of an individual who developed an intra-abdominal abscess following a spillage of gallstones, which occurred after a laparoscopic cholecystectomy that was performed more than a decade ago. Herein, we also discuss the findings of a literature review that highlights the clinical presentations of an intra-abdominal abscess formed due to gallstone spillage after a decade of the laparoscopic intervention. We also discuss the underlying pathophysiology leading to abscess formation, the imaging modalities used to visualize the abscess, as well as the therapeutic strategy used to treat this rare clinical entity.

Categories: Gastroenterology, General Surgery, Infectious Disease

Keywords: spilled gallstones, abdominal abscess, laparoscopic cholecystectomy

\section{Introduction}

Laparoscopic cholecystectomy is the prevailing treatment option for cholelithiasis, and the procedure is associated with low morbidity and mortality. However, the practice of laparoscopy has also led to the advent of difficult complications such as gallbladder perforation and the intraoperative spillage of gallstones. Gallbladder perforations can occur in up to $40 \%$ of laparoscopic cholecystectomies while the incidence of gallstone spillage can range from 6\%$30 \%$ [1]. We present a case and a literature review related to this clinical procedure, characterized by the formation of intra-abdominal abscesses that manifested clinically after more than a decade of undergoing an operative intervention.

\section{Case Presentation}

A 78-year-old male with multiple comorbidities, including hypertension, hyperlipidemia, and type II diabetes mellitus, presented to our emergency setting with complaints of recurrent bouts of abdominal pain and fluctuating fevers for the previous two weeks. The patient reported that the pain is a new manifestation of a previously dull aching pain that had waxed and waned over the last decade. His description alluded to a pain that was sharp and intermittent with localization in the right upper quadrant. He could not attribute the intermittent nature of his predicament to any aggravating or relieving influences. The pain was 
associated with fluctuating low-grade fevers $\left(99^{\circ} \mathrm{F}-100^{\circ} \mathrm{F}\right)$, anorexia, and an associated 13pound weight loss, which culminated in a visit to our clinical setup.

Further interrogation disclosed that the patient underwent a laparoscopic cholecystectomy in 2003. The ensuing year was relatively pain-free but was followed by recurrent bouts of right upper quadrant pain, albeit less upsetting than his current presentation. He was subsequently diagnosed in 2005 with gallstone spillage. The patient chose conservative treatment for his abdominal pain, rather than invasive interventions, which included the administration of acetaminophen and non-steroidal anti-inflammatory drugs (NSAIDs). This treatment modality was sufficient for the duration of a decade. He presented to another medical facility with similar complaints of fever and abdominal pain in 2016. A computed tomography (CT) scan of his abdomen disclosed the presence of a necrotic phlegmon, which was subjected to aspiration. Its composition included a combination of fibrous material, granulation tissue, and inflammatory infiltrate. The aspiration provided considerable relief of symptoms and he was discharged on a gabapentin prescription that was well-tolerated and produced sustained amelioration of his pain, with only occasional wavering with respect to his baseline.

The initial assessment showed an elderly gentleman, who was alert and well-orientated but under considerable distress due to the abdominal pain and accompanying chills. He had a fever of $104^{\circ} \mathrm{F}$, a heart rate of 120 beats per minute, a blood pressure of $95 / 70 \mathrm{~mm} \mathrm{Hg}$, and a respiratory rate of 19 per minute. An abdominal exam revealed a non-protuberant, soft, and tender abdomen with marked sensitivity in the right upper quadrant. He had perceptible bowel sounds, an absence of dullness on percussion, and a clear rectal vault. Pertinent initial laboratory investigations included an elevated white blood cell (WBC) count of $16,900 / \mu \mathrm{L}, \mathrm{C}$ reactive protein (CRP) of $6.5 \mathrm{mg} / \mathrm{dL}$, and a random blood glucose (RBG) of $280 \mathrm{mg} / \mathrm{dL}$. The patient subsequently underwent a whole body CT scan, which revealed a large 19-cm subdiaphragmatic, right retroperitoneal abscess, which was inferior and posterior to the right hepatic lobe (Figure 1). 


\section{Cureus}

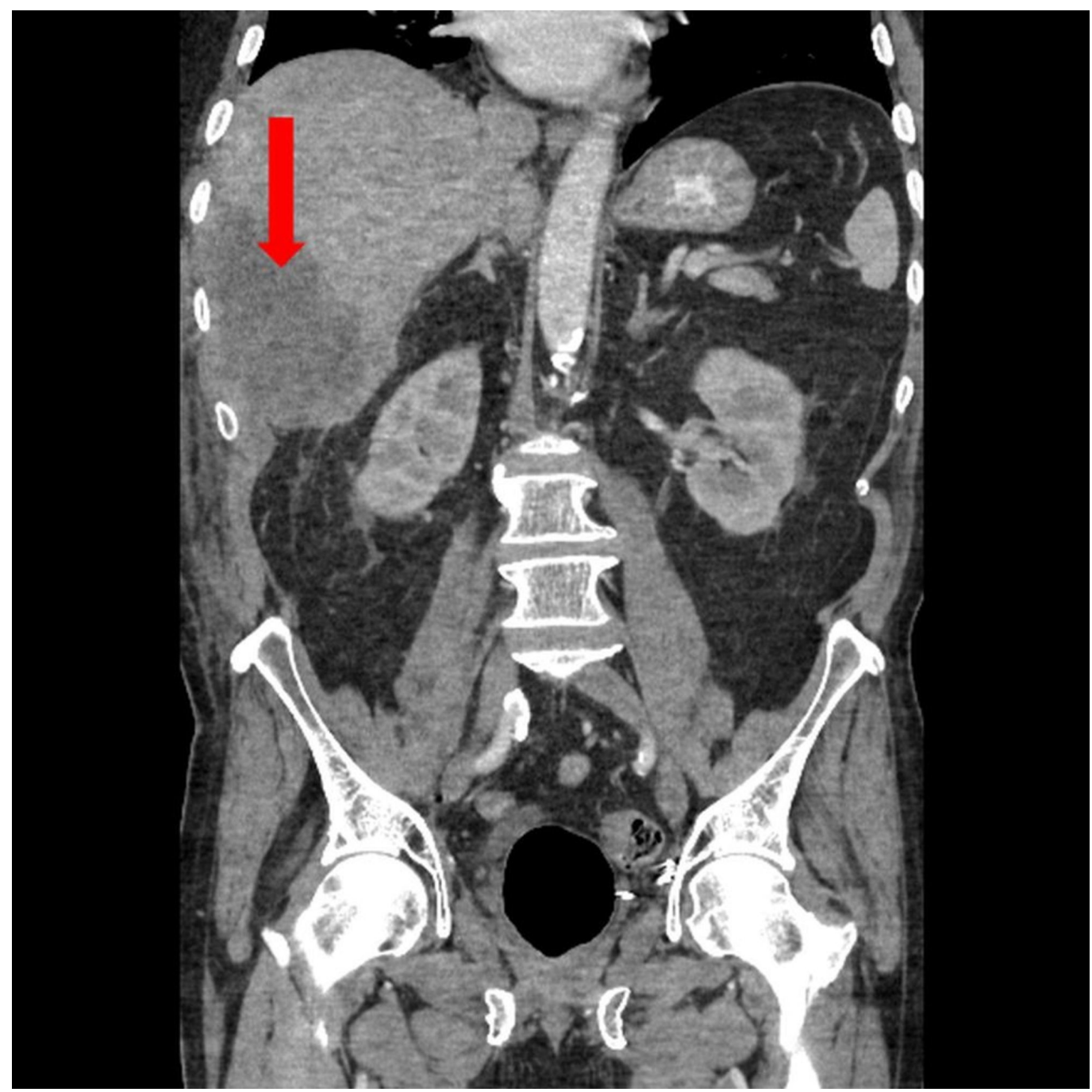

FIGURE 1: Whole body computed tomography scan showing a large 19-cm sub-diaphragmatic and a right retro-peritoneal abscess inferior and posterior to the right hepatic lobe (red arrow)

In lieu of these findings, the patient was admitted and started on a combination of intravenous fluids, intravenous (IV) vancomycin and piperacillin-tazobactam due to an underlying suspicion of sepsis secondary to a hepatic and/or perihepatic liver abscess caused by a lack of gallstone retrieval following his cholecystectomy. He was subsequently subjected to a percutaneous CT-guided drain placement, which allowed for the evacuation of approximately $700 \mathrm{~mL}$ of grossly purulent material and provided prompt pain relief. The fluid sample was sent for a gram stain, culture, and a bilirubin assay. The gram stain of the abscess fluid revealed branching gram-positive rods concerning for Actinomyces, Nocardia, and Streptomyces; therefore, the patient remained on IV vancomycin and piperacillin-tazobactam, with the addition of trimethoprim-sulfamethoxazole (TMP-SMX) to the antibiotic regimen. Remarkably, the culture growth was positive for Propionibacterium and ampicillin-sulbactam was added to the list of antibiotics. Two days later, the patient was shifted to the intensive care unit (ICU) following unrelenting fever and persistent tachycardia, even after his abdominal drain placement was supplemented with vigorous antibiotic and antipyretic therapy. His ICU stay was complicated by episodes of dyspnea, tachypnea, and pleuritic chest pain, while a chest 


\section{Cureus}

auscultation unveiled a decrease in breath sounds at the right basal region. A repeat CT scan confirmed the reduction in the size of the abscess and showed a new right-sided pleural effusion, which explained the patient's breathing difficulties (Figure 2).

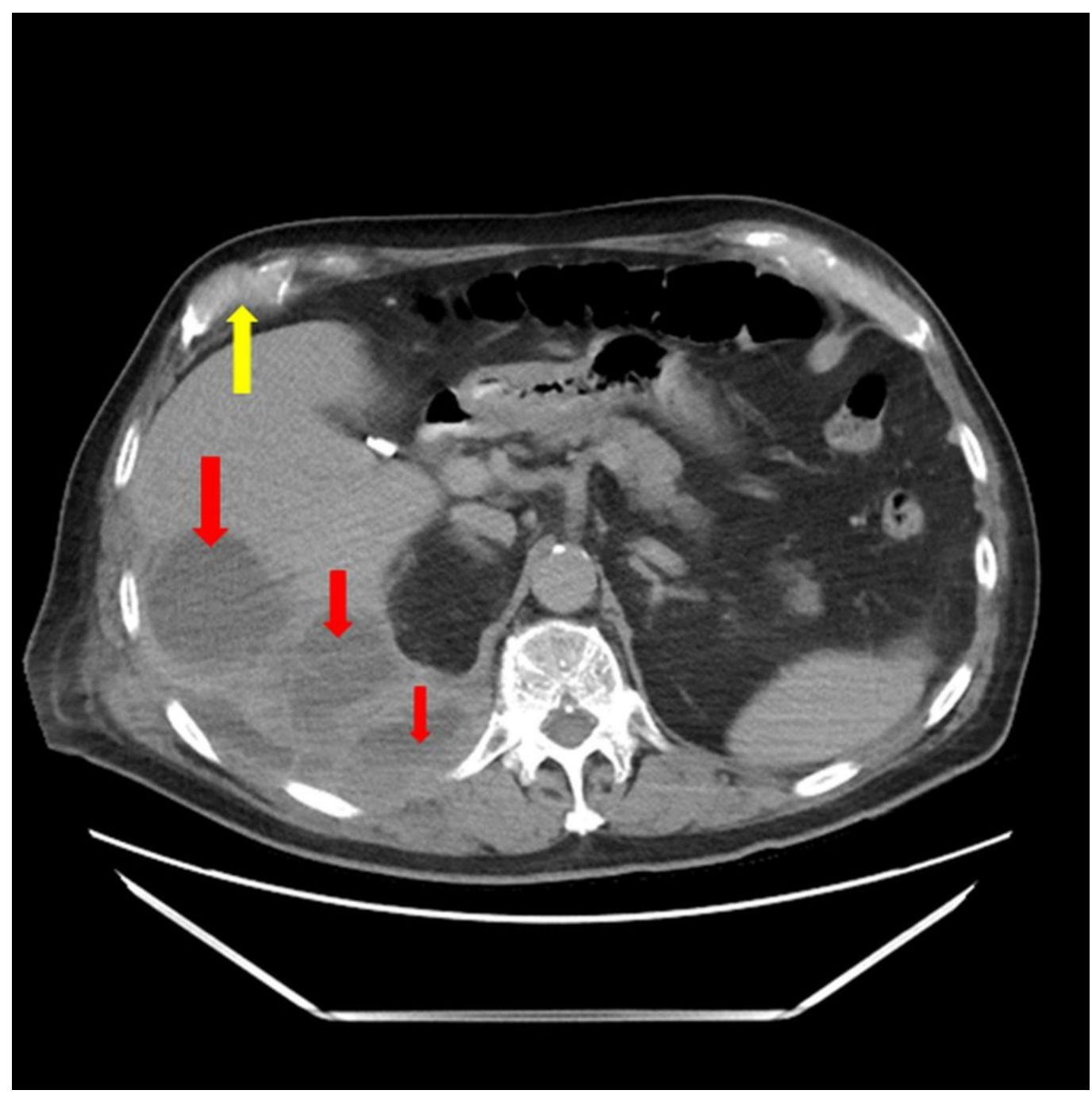

FIGURE 2: Abdominal computed tomography scan shows a diminished right retro-peritoneal collection inferior and posterior to the right hepatic lobe (red arrows), with a rightsided partially loculated pleural effusion (yellow arrow)

The patient underwent an ultrasound-guided chest tube placement, which evacuated $10 \mathrm{~mL}$ of purulent fluid, followed by two doses of lytic therapy with tissue plasminogen activator (tPA) via the catheter. The following morning, he described an aggravation in his pleuritic chest pain, and an episode of shortness of breath, whereby, the oxygen saturation dipped to $90 \%$. A new chest CT scan was ordered, which showed an interval increase in the right basilar opacity with a moderately sized pleural effusion (Figure 3). 


\section{Cureus}

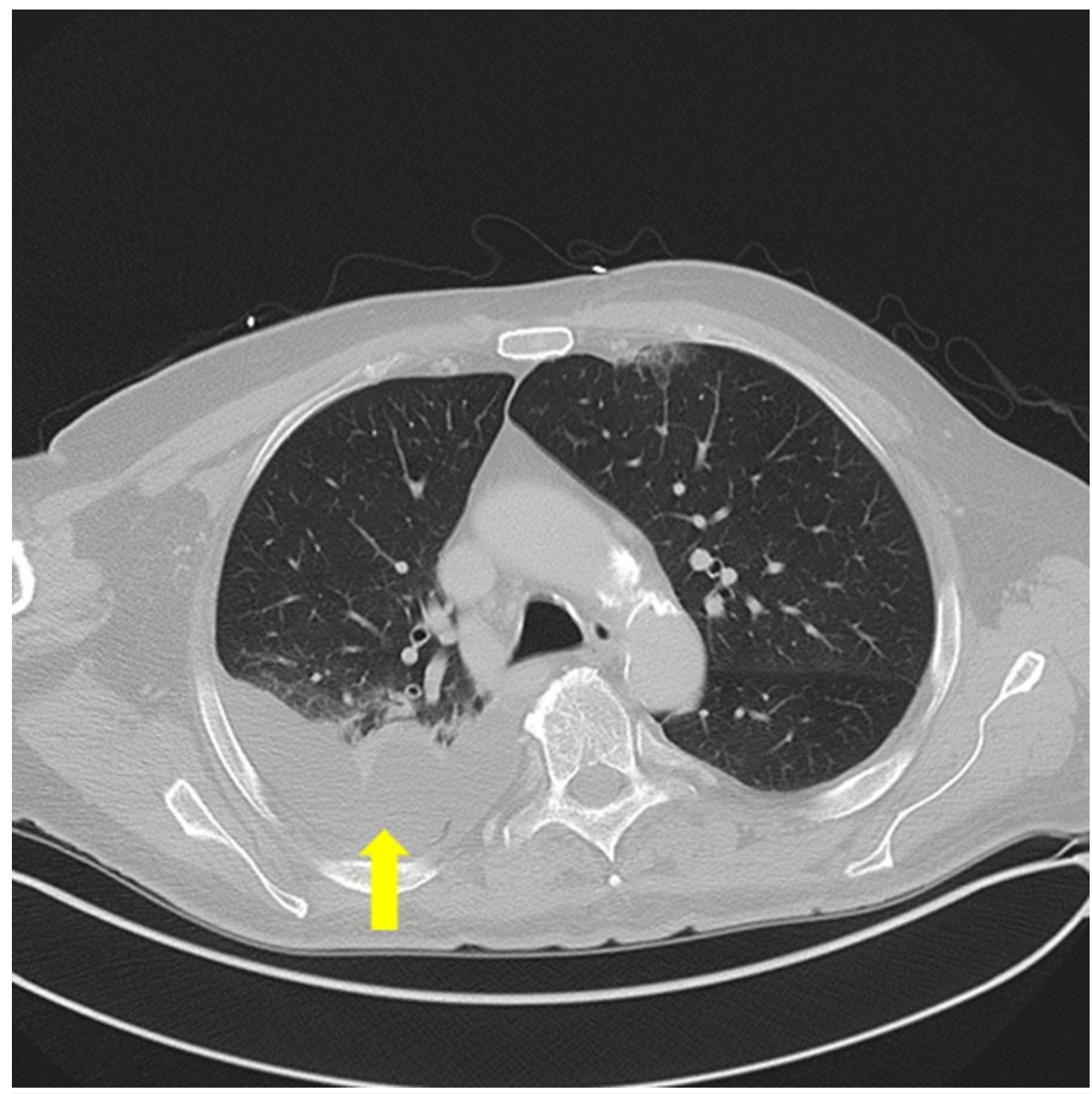

FIGURE 3: Chest computed tomography scan showing a rightsided basilar opacity with a moderate-sized pleural effusion (yellow arrow)

He was subsequently upgraded to a larger catheter via a CT-guided approach that evacuated a total of $900 \mathrm{~mL}$ of purulosanguinos fluid. The patient tolerated subsequent lytic therapies well and showed vast clinical improvement following this procedure, with a reduction in dyspnea, pleuritic chest pain, and fever, as well as a down-trending of his inflammatory markers.

A repeat CT scan was performed on the 10th day of admission, which revealed a near-complete resolution of his right-sided pleural effusion, and a decrease in his right-sided retrohepatic intrabdominal abscess (Figure 4). 


\section{Cureus}

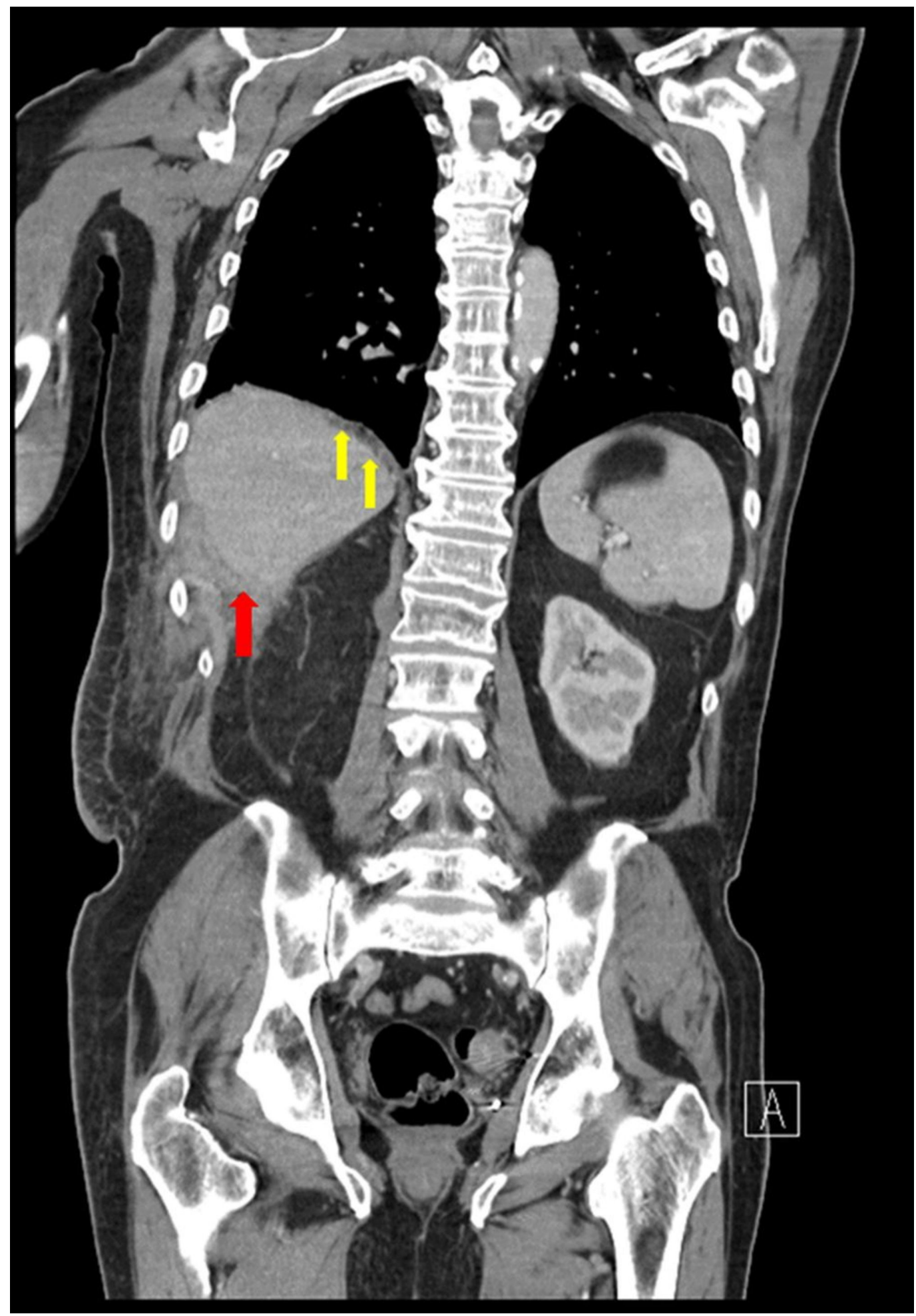

FIGURE 4: Whole body computed tomography scan showing a diminishing abscess in the inferoposterior aspect of the right hepatic lobe (red arrow) with a diminishing right-sided pleural effusion (yellow arrows). 
pain control. The patient was shifted to oral amoxicillin-clavulanate a month after the resolution of his pain, fever, and stabilization of inflammatory markers. The transhepatic percutaneous drain was left in place in order to allow for the formation of a chronic drainage tract, with hopes of localizing the perpetrating gallstones at its base.

Two months after discharge, the patient underwent a procedure for upsizing the drain in order to accommodate for a choledochoscope into the abscess cavity and the maturing sinus tract. He subsequently underwent an abscess cavity endoscopy, whereby a catheter and scope were advanced into the cavity for exploration. An abscess catheter study was performed through the existing catheter and showed no filling defects, after which the catheter was removed and an endoscope was inserted for direct visualization of the main cavity, as well as the two "fingers" branching out of the abscess cavity. Two small stones were expelled after flushing the main cavity multiple times. Following the expulsion of the gallstones, a replacement catheter was advanced into the cavity and a second catheter study was performed to rule out the possibility of any other stones. The patient tolerated this intervention well and had no further drainage from the intra-abdominal drain.

Following a lack of drain output and resolution of symptoms after his last endoscopic procedure a month ago, the patient's intra-abdominal drain was removed. The patient is currently stable and is being followed as an outpatient to date.

\section{Discussion}

The complication of gallstone spillage following cholecystectomy is mostly affiliated with novel laparoscopic intervention. Papasavas et al. concluded that out of 129 cases of gallstone spillage, the conservative open approach had only two cases of this subsequent complication [2]. An array of various factors subsequently disposes to perforation such as the dissection of the gallbladder from the liver bed, the application of undue retraction of the gallbladder via forceps, as well as gallbladder extraction, which can also potentiate spillage [3].

As illustrated, the risk of perforation and spillage is high [1]. However, the subsequent development of actual complications secondary to a stone spillage is relatively rare, with an estimated incidence of $0.8 \%-8.5 \%$ [3]. This alludes to the understanding that certain risk factors influence the possibility of developing complications. A consensus exists that any factor can conceivably precipitate to infection due to the risk of introducing infective pathogens into the peritoneum. Some of these instigators include advanced age, male gender, a simultaneous existence of acute cholecystitis, and the presence of multiple $(>15)$, sizable $(>1.5 \mathrm{~cm})$, or pigmented gallstones [4].

The most common complication of the spillage is the resultant formation of an intra-abdominal and abdominal wall abscess [5]. Pigmented stones and nonsterile bile contain infective pathogens, and the presence of either subsequently enhances the risk of abdominal abscesses [1]. It is for these reasons that most abscesses contain the same flora as that of an infected gallbladder, such as Escherichia coli [3]. Our patient presented with an abdominal abscess after a laparoscopic cholecystectomy, which was performed more than 10 years ago. An indolent course such as this can be ascribed to the presence of sterile gallstones within the abdominal cavity, which ultimately manifests as an abscess following the invasion of the bloodstream by a pathological organism. A subsequent infection of the calculus and its adjacent vicinity may lead to a localized inflammatory response, which consequently leads to the formation of an abdominal abscess [6]. Another postulation considers the presence of an insulative plate around the stone, which gradually deteriorates over time and, subsequently, predisposes the stone to an infection and resultant abscess formation [3]. A literature review conducted on 91 patients by Brockman et al. identifies subhepatic abscesses as the most common abscesses (34.1 $\%)$, followed by subphrenic (15.9\%) and ovarian abscesses (11.4\% ). Other, less-common 
adverse outcomes include bowel obstruction and perforation (2.2\%), peritonitis (3.3\%), fistula formation (12.1\%), ileus (2.2\%), empyema, broncholithiasis, and cholelithoptysis through a peritoneo-pleuro-bronchial fistula [7-8].

The clinical presentation of an abdominal abscess is dynamic and mostly depends on the location of the abscess. Most features are non-specific and include low-grade fever, anorexia, weight loss, persistent abdominal pain, specific tenderness at the site of the abscess, and paralytic ileus. Laboratory evaluation may show leukocytosis, elevated erythrocyte sedimentation rate (ESR), and blood culture may reveal polymicrobial growth $[2,9]$. However, there have been cases of abdominal abscesses which are clinically silent and only identified following routine radiological investigations [10].

Diagnosis is challenging due to the unusual location of the abscess. It is additionally problematic in cases where there is no official documentation of a gallstone spillage [4]. Such outcomes underscore the significance of radiological imaging in the visualization of an abscess. Most common modalities include ultrasonic imaging, computed tomography (CT) scans, and magnetic resonance imaging (MRI). On ultrasonography, radiolucent gallstones are often visualized as hyper-echoic entities, which are bordered by aggregates of fluid or necrotic collections. The overlying calcification of the gallstones could render them radiopaque. Such stones can be visualized on CT imaging as hyperdense lesions while MRI scans could reveal a signal void, characterized by the presence of a blank space in a fluid-filled accumulate $[1,11]$.

The management of spilled stones is multifaceted. The presence of an associated abscess warrants the utilization of antibiotics that target gastrointestinal microorganisms [2]. We suspected that our patient was septic and provided him with broad-spectrum antibiotic coverage. A lack of symptom resolution warranted the utilization of interventional modalities. A needle aspiration is necessary to verify the presence of an abscess, as imaging techniques may not be able to discriminate between other mass collections such as a biloma or a hematoma. The insertion of a pigtail catheter allows for the evacuation of purulent contents and helps in the abatement of sepsis. A CT-guided approach is usually preferred due to its ability to provide an accurate assessment of the extent of fluid pockets and the presence of underlying complications of inflammation such as adhesions. The tract formed by the sinus is then dilated after a few weeks and the abscess at the base of the canal is assessed via an abscessogram, which allows for the visualization of the cavity, the presence of gallstones, as well as any associated leading tracks. A nephroscope can be passed through the canal to assist in the subsequent stone evacuations. The size of the stone(s) guides further management. Stones less than $1 \mathrm{~cm}$ in size can be scooped via a basket; however, stones greater than $1 \mathrm{~cm}$ in size may warrant splintering to make evacuation easier. This can be accomplished by mechanical means or ultrasonic lithotripsy, but shattering stones could lead to the formation of smaller remnants, which may endure a resultant evacuation and instigate a secondary inflammatory response down the road. Following the procedure, a second abscessogram ensures that all gallstones have been evacuated and a secondary catheter is to be left in place and flushed regularly. Indications for its eventual removal include a cessation of primary clinical manifestations and an output of less than $10 \mathrm{~mL}$ per day $[1,9]$.

We conducted a literature review of abdominal abscesses that developed after 10 (or more) years since a laparoscopic cholecystectomy utilizing PubMed. Our evaluation concluded that nine such cases have been previously reported, with our case being the 10th. The mean age of these patients was 59.6 years, ranging from 28 to 77 years. An overwhelming female predominance was observed (89\%). Most common complaints included abdominal pain (78\%), swelling (56\%), and fever (33\%) with the associated laboratory investigations, including leukocytosis (44\%) and elevated CRP (22\%). Commonly isolated organisms included Enterococcus faecalis, Clostridium perfringens, Actinomyces israelii, Enterobacter aerogenes, and Escherichia coli. The locations of abscesses varied considerably with each case, ranging from the 


\section{Cureus}

pouch of Douglas to the subhepatic and perihepatic regions. Some cases were complicated by the extension of the abscesses to the lower back and the retroperitoneum. Most abscesses were treated with a combination of antibiotics and percutaneous drainage, but open laparotomies were performed in complicated cases. A majority of the patients $(78 \%)$ have had a favorable clinical outcome to date (Table 1).

\begin{tabular}{|c|c|c|c|c|c|c|c|c|}
\hline PUBLICATION & AGE & SEX & $\begin{array}{l}\text { TIME SINCE } \\
\text { LAPAROSCOPIC } \\
\text { CHOLECYSTECTOMY }\end{array}$ & $\begin{array}{l}\text { CLINICAL } \\
\text { PRESENTATION }\end{array}$ & SITE OF ABSCESS & $\begin{array}{l}\text { DIAGNOSTIC } \\
\text { MODALITY }\end{array}$ & TREATMENT & OUTCOME/RECOVERY \\
\hline $\begin{array}{l}\text { Christensen et } \\
\text { al. [3] }\end{array}$ & $\begin{array}{l}53 \\
\text { years }\end{array}$ & $\mathrm{F}$ & 17 years & $\begin{array}{l}\text { Rectal pain, incomplete } \\
\text { defecation, and feeling of } \\
\text { lower abdominal } \\
\text { heaviness }\end{array}$ & $\begin{array}{l}\text { Recto-uterine pouch } \\
\text { (pouch of Douglas) }\end{array}$ & CT scan & $\begin{array}{l}\text { Transvaginal drainage of the } \\
\text { abscess }\end{array}$ & Uneventful \\
\hline $\begin{array}{l}\text { Bartels et al. } \\
\text { [5] }\end{array}$ & $\begin{array}{l}72 \\
\text { years }\end{array}$ & $\mathrm{F}$ & 10 years & $\begin{array}{l}\text { Intermittent, right upper } \\
\text { quadrant abdominal and } \\
\text { right-sided flank pain }\end{array}$ & Subhepatic & CT scan & $\begin{array}{l}\text { Drainage of the abscess via } \\
\text { exploratory laparotomy } \\
\text { following failed ultrasound- } \\
\text { guided drainage }\end{array}$ & Uneventful \\
\hline $\begin{array}{l}\text { Pottakkat et al. } \\
\text { [6] }\end{array}$ & $\begin{array}{l}28 \\
\text { years }\end{array}$ & $\mathrm{F}$ & 11 years & $\begin{array}{l}\text { Painful and tender } \\
\text { swelling in the right } \\
\text { upper quadrant of the } \\
\text { abdomen }\end{array}$ & Perihepatic & CT scan & $\begin{array}{l}\text { Drainage of the abscess via an } \\
\text { open exploration }\end{array}$ & Uneventful \\
\hline $\begin{array}{l}\text { Stupak et al. } \\
\text { [12] }\end{array}$ & $\begin{array}{l}72 \\
\text { years }\end{array}$ & $\mathrm{F}$ & 11 years & $\begin{array}{l}\text { Fever, nausea, anorexia, } \\
\text { and right upper quadrant } \\
\text { abdominal pain }\end{array}$ & Subhepatic & CT scan & $\begin{array}{l}\text { Percutaneous drainage of the } \\
\text { abscess and intravenous } \\
\text { clindamycin }\end{array}$ & Uneventful \\
\hline $\begin{array}{l}\text { Arishi et al. } \\
\text { [13] }\end{array}$ & $\begin{array}{l}45 \\
\text { years }\end{array}$ & $\mathrm{F}$ & 15 years & $\begin{array}{l}\text { Colicky, central } \\
\text { abdominal pain and } \\
\text { swelling }\end{array}$ & Upper abdomen & CT scan & Surgical removal of the cyst & $\begin{array}{l}\text { A wound infection } 2 \\
\text { weeks } \\
\text { postoperatively; managed } \\
\text { with debridement and } \\
\text { antibiotics }\end{array}$ \\
\hline $\begin{array}{l}\text { Bașak et al. } \\
\text { [14] }\end{array}$ & $\begin{array}{l}77 \\
\text { years }\end{array}$ & $\mathrm{M}$ & 10 years & Vague abdominal pain & $\begin{array}{l}\text { Three abscesses } \\
\text { extending from the } \\
\text { posterior aspect of the } \\
\text { liver to the right flank }\end{array}$ & CT scan & $\begin{array}{l}\text { Ultrasound-guided } \\
\text { percutaneous drainage of the } \\
\text { abdominal abscess. The flank } \\
\text { abscess was managed with an } \\
\text { open incision and drainage }\end{array}$ & Uneventful \\
\hline $\begin{array}{l}\text { Nugent et al. } \\
\text { [15] }\end{array}$ & $\begin{array}{l}73 \\
\text { years }\end{array}$ & $\mathrm{F}$ & 20 years & $\begin{array}{l}\text { Pain in the lower back } \\
\text { and the right gluteal } \\
\text { region on walking; } \\
\text { presence of a swelling } \\
\text { over the right flank }\end{array}$ & $\begin{array}{l}\text { Right paracolic gutter, } \\
\text { communicating with an } \\
\text { abscess in the superficial } \\
\text { tissues of the right lower } \\
\text { back }\end{array}$ & $\begin{array}{l}\text { MRI scan of } \\
\text { the abdomen } \\
\text { and pelvis }\end{array}$ & $\begin{array}{l}\text { Laparoscopic drainage of the } \\
\text { abscess and a retrieval of the } \\
\text { dropped gallstone }\end{array}$ & $\begin{array}{l}\text { Formation of a peritoneo- } \\
\text { cutaneous fistula, which } \\
\text { was left to heal by } \\
\text { secondary intention }\end{array}$ \\
\hline Oh et al. [16] & $\begin{array}{l}73 \\
\text { years }\end{array}$ & $\mathrm{F}$ & 15 years & Abrupt abdominal pain & $\begin{array}{l}\text { Intra-abdominal abscess } \\
\text { abutting the abdominal } \\
\text { wall }\end{array}$ & CT scan & $\begin{array}{l}\text { followed by laparoscopic stone } \\
\text { removal and abscess drainage }\end{array}$ & Uneventful \\
\hline $\begin{array}{l}\text { Hussain et al. } \\
\text { [17] }\end{array}$ & $\begin{array}{l}43 \\
\text { years }\end{array}$ & $\mathrm{F}$ & 10 years & $\begin{array}{l}\text { Fever, tender swelling, } \\
\text { and surrounding cellulitis }\end{array}$ & $\begin{array}{l}\text { Antero-lateral abdominal } \\
\text { wall of the right lumbar } \\
\text { region extending to the }\end{array}$ & CT scan & $\begin{array}{l}\text { Incision and drainage followed } \\
\text { by secondary closure of the }\end{array}$ & Uneventful \\
\hline
\end{tabular}




\section{Cureus}

\section{TABLE 1: Literature review of all the cases of abdominal abscesses that developed due to gallstone spillage after 10 (or more) years since a laparoscopic cholecystectomy, utilizing PubMed}

M: Male; F: Female; CT: Computed Tomography; MRI: Magnetic Resonance Imaging

\section{Conclusions}

Laparoscopic cholecystectomy is the gold standard for the treatment of gallstones. However, this new therapeutic modality brings new clinical challenges, such as gallstone spillage, which can lead to intra-abdominal abscesses. This may present acutely or even more than a decade later (as explained earlier). The clinical presentation is vague and presents a diagnostic challenge, which underscores the fact that treating physicians must harbor an adequate suspicion for this clinical entity, especially in patients with a previous history of laparoscopic cholecystectomy. Management focuses on a combination of antibiotic therapy and minimally invasive procedures that allow for abscess drainage, evacuation of gallstones, and subsequent resolution of symptoms.

\section{Additional Information}

\section{Disclosures}

Human subjects: Consent was obtained by all participants in this study. Conflicts of interest: In compliance with the ICMJE uniform disclosure form, all authors declare the following: Payment/services info: All authors have declared that no financial support was received from any organization for the submitted work. Financial relationships: All authors have declared that they have no financial relationships at present or within the previous three years with any organizations that might have an interest in the submitted work. Other relationships: All authors have declared that there are no other relationships or activities that could appear to have influenced the submitted work.

\section{References}

1. Sathesh-Kumar T, Saklani AP, Vinayagam R, Blackett RL: Spilled gall stones during laparoscopic cholecystectomy: a review of the literature. Postgrad Med J. 2004, 80:77-79. 10.1136/pmj.2003.006023

2. Papasavas PK, Caushaj PF, Gagne DJ: Spilled gallstones after laparoscopic cholecystectomy . J Laparoendosc Adv Surg Tech A. 2002, 12:383-386. 10.1089/109264202320884144

3. Christensen AM, Christensen MM: Abdominal wall abscess containing gallstones as a late complication to laparoscopic cholecystectomy performed 17 years earlier. J Surg Case Rep. 2013, 2013:10.1093/jscr/rjs038

4. Ologun GO, Lovely R, Sultany M, Aman M: Retained gallstone presenting as large intraabdominal mass four years after laparoscopic cholecystectomy. Cureus. 2018, 10:2030. Accessed: June 2018: 10.7759/cureus.2030

5. Bartels AK, Murali AR, Zamora JG: Subhepatic sterile abscess 10 years after laparoscopic cholecystectomy. ACG Case Rep J. 2015, 2:113-115. 10.14309/crj.2015.22

6. Pottakkat B, Sundaram M, Singh P: Abdominal wall abscess due to spilled gallstone presenting 11 years after laparoscopic cholecystectomy. Clin J Gastroenterol. 2010, 3:324-326. 10.1007/s12328-010-0180-y

7. Brockmann JG, Kocher T, Senninger NJ, Schürmann GM: Complications due to gallstones lost 
during laparoscopic cholecystectomy. Surg Endosc. 2002, 16:1226-1232. 10.1007/s00464-0019173-8

8. Hawasli A, Schroder D, Rizzo J, Thusay M, Takach TJ, Thao U, Goncharova I: Remote complications of spilled gallstones during laparoscopic cholecystectomy: causes, prevention, and management. J Laparoendosc Adv Surg Tech A. 2002, 12:123-128.

$10.1089 / 10926420252939664$

9. Men S, Akhan O, Koroglu M: Percutaneous drainage of abdominal abcess . Eur J Radiol. 2002, 43:204-218. 10.1016/S0720-048X(02)00156-0

10. Goldman R, Hunter TB, Haber K: The silent abdominal abscess: role of the radiologist . AJR Am J Roentgenol. 1983, 141:21-25. 10.2214/ajr.141.1.21

11. Thurley PD, Dhingsa R: Laparoscopic cholecystectomy: postoperative imaging. AJR Am J Roentgenol. 2008, 191:794-801. 10.2214/AJR.07.3485

12. Stupak D, Cohen S, Kasmin F, Lee Y, Siegel JH: Intra-abdominal actinomycosis 11 years after spilled gallstones at the time of laparoscopic cholecystectomy. Surg Laparosc Endosc Percutan Tech. 2007, 17:542-544. 10.1097/SLE.0b013e3181469069

13. Arishi AR, Rabie ME, Khan MS, Sumaili H, Shaabi H, Michael NT, Shekhawat BS: Spilled gallstones: the source of an enigma. JSLS. 2008, 12:321-325.

14. Basak F, Kinaci E, Dincel O, Aren A: The unexpected late complication due to spilled gallstones: collect as much as possible the next time [Article in Turkish, English]. Istanbul Med J. 2016, 17:68-69. 10.5152/imj.2016.97752

15. Nugent L, Chandran P: Need brooks no delay. Peritoneo-cutaneous fistula formation secondary to gallstone dropped at laparoscopic cholecystectomy 20 years previously: a case report. J Surg Case Rep. 2018, 2018:13. 10.1093/jscr/rjy013

16. Oh HY, Lee HS, Bae SY, Park JY, Lee SG, Kwon BS, Kim JN: An intra-abdominal abscess as a late complication of laparoscopic cholecystectomy [Article in Korean]. Korean J Med. 2012, 83:93-96. 10.3904/kjm.2012.83.1.93

17. Hussain MI, Al-Akeely MH, Alam MK, Al-Abood FM: Abdominal wall abscess following laparoscopic cholecystectomy: an unusual late complication of lost gallstones. J Coll Physicians Surg Pak. 2010, 20:763-765. 